\title{
Life history variation in space and time: environmental and seasonal responses of a parthenogenetic invasive freshwater snail in northern Germany
}

\author{
Gerlien Verhaegen (iD) Kai von Jungmeister $\cdot$ Martin Haase $\mathbb{D}$
}

Received: 20 September 2019/Revised: 3 June 2020/ Accepted: 16 June 2020/Published online: 27 July 2020

(C) The Author(s) 2020

\begin{abstract}
The processes that lead to a successful invasion are complex. Here, we investigated life history characteristics potentially explaining the invasion success of Potamopyrgus antipodarum, a small parthenogenetic and ovoviviparous freshwater snail that was recently added to the top "hundred worst" alien species in Europe. We monitored monthly, over the course of 1 year, shell size, number of brooded embryos, and the presence of castrating parasites at
\end{abstract}

Guest editors: Katya E. Kovalenko, Fernando M. Pelicice, Lee B. Kats, Jonne Kotta \& Sidinei M. Thomaz / Aquatic Invasive Species III

Electronic supplementary material The online version of this article (https://doi.org/10.1007/s10750-020-04333-8) contains supplementary material, which is available to authorized users.

\section{Present Address:}

G. Verhaegen $(\varangle)$

Advanced Science-Technology Research (ASTER)

Program, Institute for Extra-cutting-edge Science and

Technology Avant-garde Research (X-star), Agency for

Marine-Earth Science and Technology (JAMSTEC), 2-15,

Natsushimacho, Yokosuka, Kanagawa 237-0061, Japan

e-mail: gerlienverhaegen@hotmail.com

\section{Haase}

e-mail: martin.haase@uni-greifswald.de

G. Verhaegen · K. von Jungmeister · M. Haase AG Vogelwarte, Zoologisches Institut und Museum, Universität Greifswald, Soldmannstraße 23, 17489 Greifswald, Germany three Northeast German sites: a lake (the Kiessee), a stream (Hohen Sprenz), and a small spring brook (Rügen) $(N=1165)$. We found that (1) despite sharing the same clonal lineage, drastic differences in space and time for size and fecundity were observed, and these differences were linked to specific environmental variables (water temperature, salinity, and current); (2) P. antipodarum reproduces all year around, except at one of our sites, the spring Rügen, where the reproduction was seasonal; (3) none of our dissected specimens was infected by parasites. Together with ovoviviparity and the ability to reproduce parthenogenetically while being released from parasite pressure, the ability to adapt readily to a wide range of habitat conditions is likely paramount for the invasive success of $P$. antipodarum.

Keywords Potamopyrgus antipodarum $\cdot$ New Zealand mud snail $\cdot$ Shell size $\cdot$ Fecundity $\cdot$ Plasticity · Adaptation · Invasive species

\section{Introduction}

Biological invasions represent a major ecological and economic threat (Pimentel et al., 2006; Nentwig, 2007) and are even viewed as a component of global change (Vitousek et al., 1996). Invasive species have often been attributed with specific life history characteristics. For instance, once the transportation and establishment phase have been overcome (Sakai et al., 
2001), high growth rate and reproduction often allow for rapid spread of invasive species by outcompeting native populations. Astounding examples comprise the Nile perch Lates niloticus (Linnaeus, 1758) in Lake Victoria (Goldschmidt, 1996) and the zebra mussel Dreissena polymorpha (Pallas, 1771) in the northern USA (Caraco et al., 1997) that caused the extinction of native species and profound ecological changes. The adaptability to novel environments has also been considered a key feature in the range expansion success of invasive species (e.g., Eriksen et al., 2012; Mccann et al., 2014; Verhaegen et al., 2018a), including the adaptation of their life history traits (e.g., Dlugosch \& Parker, 2008; Jaspers et al., 2014; Li et al., 2015). Studying the adaptation of life history traits of invasive species to their new habitat is, therefore, crucial for two reasons. First of all, it is essential to reveal predispositions of species to become successful invaders or pioneers (Sakai et al., 2001) to prevent, manage, and mitigate biological invasions. Second, invasive species can be used as models providing insights on how organisms will cope with the consequences of current human-enhanced environmental change, as by definition the habitat they invade is new (Sakai et al., 2001).

In the present study, we investigated the spatial and temporal fluctuations in the life history traits size and fecundity of small invasive fresh and brackishwater snail Potamopyrgus antipodarum (Gray, 1843) in northern Germany. Commonly called the New Zealand mud snail, this gastropod is native to New Zealand, but has successfully invaded fresh and brackish waters in Australia, Europe, Japan, the USA, and Chile within the last 180 years (Smith, 1889; Alonso \& Castro-Díez, 2012; Collado, 2014). Mixed populations of sexually reproducing diploid males and females coexist in the native range with parthenogenetically reproducing polyploids which are almost all females (Dybdahl \& Lively, 1995; Neiman et al., 2011). Interestingly, in the entire invaded range, however, only these clonally reproducing females can be found (Hauser et al., 1992; Hughes, 1996; Jacobsen et al., 1996; Gangloff, 1998; Weetman et al., 2002; Städler et al., 2005; Verhaegen et al., 2018a). These invasive lineages were found only by few individuals: in Europe for instance, only two mitochondrial lineages (Städler et al., 2005; Verhaegen et al., 2018a) have been identified. On the nuclear level, the diversity was somewhat higher, but the divergence estimated based on microsatellites (Weetman et al., 2002) or SNPs was fairly low suggesting post-invasion diversification (Verhaegen et al., 2018a).

The impact of this snail on its invaded habitat varies from place to place, which is possibly explained by different densities this snail can reach (Alonso \& Castro-Díez, 2012). In Australia, for instance, a positive relationship has been found between densities of $P$. antipodarum and native benthic fauna (Schreiber et al., 2002), whereas in the USA and Chile a negative effect was shown on endemic macroinvertebrate communities (Kerans et al., 2005), including snails (Richards, 2004; Riley et al., 2008; Collado et al., 2019a, b). In Europe, P. antipodarum has been recently added to the top "hundred worst" alien species (rank 42), among which it is the third "worst alien" mollusc, after D. polymorpha and the golden apple snail Pomacea canaliculata (Lamarck, 1819) (Nentwig et al., 2018). The high rank of P. antipodarum was mostly attributed to its major environmental impact on ecosystems (e.g., Hall et al., 2003) and other species through competition, a medium impact on vegetation through herbivory, and a major socioeconomic impact on animal production [e.g., on weight and health of rainbow trout (Vinson \& Baker, 2008)], although the literature investigated for the scoring was obviously not restricted to European populations (Laverty et al., 2015). Although $P$. antipodarum can dominate gastropod and mollusc communities in Europe (e.g., Gérard et al., 2003; Lewin \& Smoliński, 2006), only a weak effect on macroinvertebrate communities has been reported so far (Múrria et al., 2008; Schmidlin et al., 2012).

The invasive success of $P$. antipodarum has been attributed to various factors. Successful transportation and establishment of $P$. antipodarum has been associated with a wide tolerance to physical and chemical parameters including high salinities (e.g., Gérard et al., 2003; Leclair \& Cheng, 2011), a wide range of temperatures (e.g., Winterbourn, 1969; Hylleberg \& Siegismund, 1987), and desiccation (e.g., Richards et al., 2004; Lysne \& Koetsier, 2006). Another cause of its success is the so-called "enemy release" hypothesis (Darwin, 1859). In its native range, $P$. antipodarum is subjected to strong selective pressure by castrating parasitic trematodes (e.g., Winterbourn, 1974; Hechinger, 2012) locally favoring sexual over asexual reproduction (Bell, 1982; Jokela et al., 2009; Neiman \& Koskella, 2009; Neiman et al., 2017). In the 
invaded range, however, infections are extremely rare (e.g., Zbikowski \& Zbikowska, 2009; Gérard et al., 2017; Verhaegen et al., 2018a), this "release" allowing $P$. antipodarum to fully exploit the advantages of parthenogenetic reproduction (Lively, 1992): reproductive assurance (i.e., no need for finding mating partners) (Jain, 1976; Lloyd, 1979; Gerritsen, 1980) and no "two-fold" cost related to production of males (Maynard Smith, 1971; Gibson et al., 2017). In addition, rapid population growth, fast spread, and high competition for primary resources have been attributed to its high fecundity (Real, 1971; Lassen, 1979; Alonso \& Castro-Díez, 2008). Ovoviviparity is certainly another factor facilitating successful invasion (Collado, 2014). At last, the low genetic diversity and lack of recombination related to asexual reproduction are further compensated by this invasive snail through its ability to adapt its shell morphology, which is linked to fecundity, to the environment through phenotypic plasticity (Kistner \& Dybdahl, 2013; Verhaegen et al., 2018a).

Here, we monitored shell size and fecundity of three populations of $P$. antipodarum in Northeast Germany in monthly intervals over the course of 1 year. We tested the following three expectations that would explain the invasion success of this clonal invader: (1) despite being genetically practically identical and being geographically closely located, we expected to observe differences in the monitored life history traits among populations, and these differences to reflect temporal and spatial environmental changes encountered in their markedly different habitats-a lake, a stream, and a shallow spring brook. If differences among these populations were observed, these would most likely be due to phenotypic plasticity (Dybdahl \& Kane, 2005; Gust et al., 2011; Kistner \& Dybdahl, 2013; McKenzie et al., 2013; Verhaegen et al., 2018a, b) that shows the ability of this species to adapt its life history traits to the environment; (2) we expected $P$. antipodarum to reproduce all year around (e.g., Schreiber et al., 1998, McKenzie et al., 2013) and therefore to find both brooding females and the presence of juveniles every month; 3) according to the "enemy release" hypothesis and previous studies from the invaded range (e.g., Zbikowski \& Zbikowska, 2009, Verhaegen et al., 2018a), the absence of castrated parasites was expected. Our findings were then compared to those in the species' native range (Winterbourn, 1970a), and in other invaded territories, namely in Australia (Schreiber et al., 1998) and in the USA (McKenzie et al., 2013). Despite P. antipodarum being part of the top "hundred worst" alien species present in Europe, this is the first study that monitored in situ fluctuations in life history traits for European populations over a year. It is also the first in situ study designed with prior genetic knowledge in order to assure comparable genetic background (Verhaegen et al., 2018a).

\section{Materials and methods}

\section{Collection}

Potamopyrgus antipodarum was collected monthly between February 2017 and January 2018 (excluding October 2017) from three Northeast German sites: a lake, the Kiessee in Jarmen (referred to hereafter as Jarmen, $\mathrm{N} 53^{\circ} 55^{\prime} 44.5$, E $13^{\circ} 18^{\prime} 60.0$ ), a stream, the Mühlbach in Hohen Sprenz (Hohen Sprenz, N 53 ${ }^{\circ} 55^{\prime}$ 24.2, E $12^{\circ} 11^{\prime}$ 57.7), and a small, shallow spring brook, located in Quellsumpf Ziegensteine, Klein Stresow, on the island of Rügen (Rügen, N $54^{\circ} 21^{\prime}$ 23.7, E $13^{\circ} 36^{\prime}$ 27.0) (Fig. 1). These locations were identical to the sites with acronyms DEJAR, DEHOB/ $\mathrm{T}$, and DERUG, respectively, from Verhaegen et al. (2018a), who showed that snails collected at these locations during summer 2015 and/or 2016 shared the same mitochondrial haplotype. The populations from Hohen Sprenz and Jarmen also shared the same nuclear SNP genotypes (62 neutral loci); however, the one from Rügen differed slightly by seven substitutions (Verhaegen et al., 2018a). Snails were collected with a small dip net from the bottom or hard substrates at a maximum depth of $50 \mathrm{~cm}$ and fixed immediately in $80 \%$ ethanol. On each sampling occasion, the following environmental parameters were recorded: water temperature $\left({ }^{\circ} \mathrm{C}\right)$ and salinity (ppm) using a water tester (Milato ${ }^{\circledR}$, Germany), water current [lentic (i.e., without flow) vs. lotic (i.e., with flow)], and shade coverage $(\%)$.

Measurement of life history traits

The shells of the snails were individually photographed under a Carl Zeiss Discovery V20 microscope with a Plan Apo $\mathrm{S} \times 0.63$ objective and an AxioCam MRc camera, by identically positioning 
Fig. 1 Sampling locations

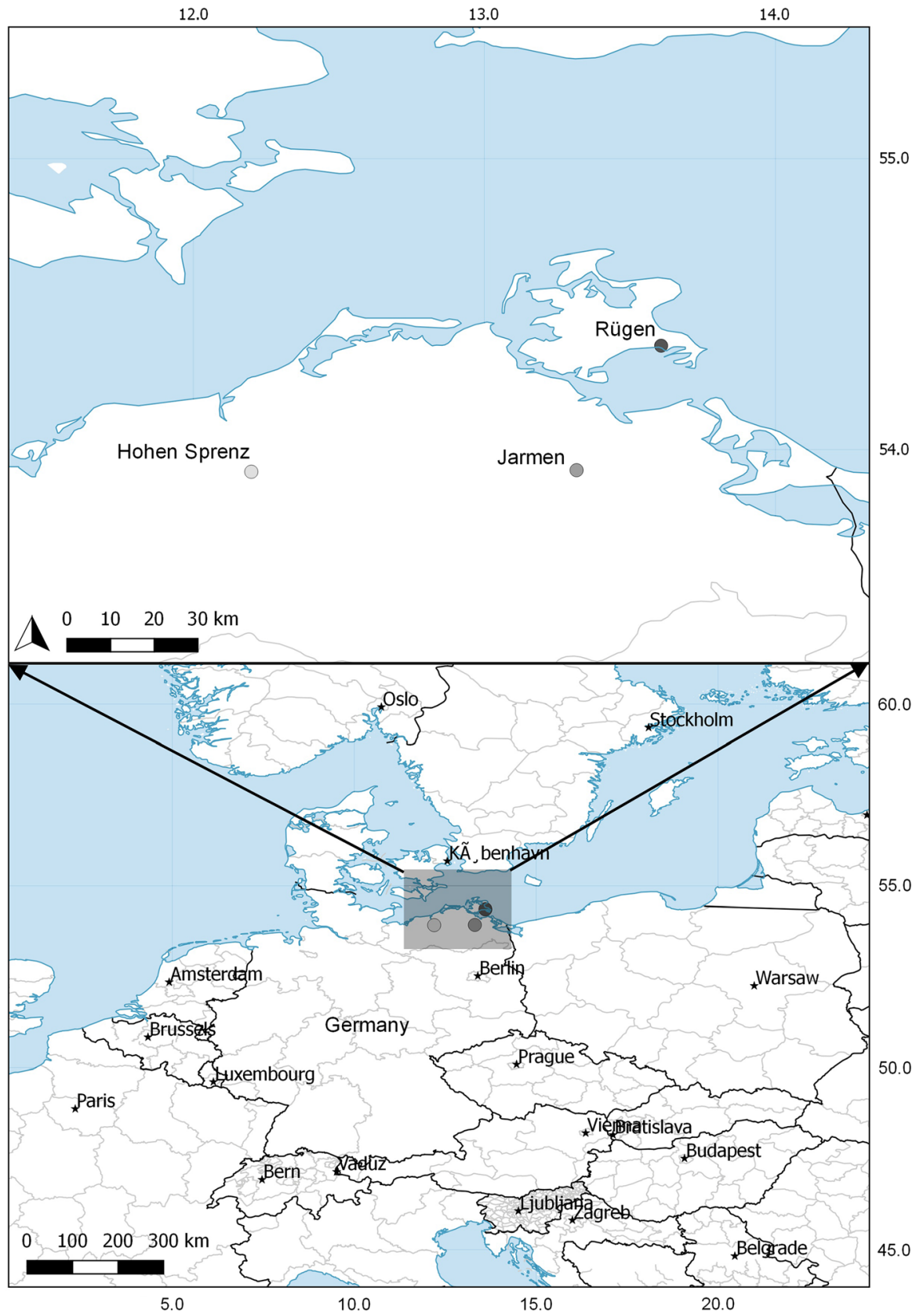

their aperture facing up and the coiling axis oriented horizontally on a silicone support. Shell height (Fig. 2) was then measured with the Axio Vision microscope software (Zeiss). To ensure that the variation in size was unrelated to manipulative error, this part was only conducted by one of us, KvJ, and a repeatability test was performed by photographing and measuring the same 29 snails twice 2 weeks apart and testing the difference in shell height with a two-sample paired $t$ test $(t=-1.427, P=0.165)$. Individuals were assigned to one of the following age classes: adult, subadult, and juvenile. An adult snail was defined as a fully grown individual displaying a continuous apertural lip (Verhaegen et al., 2018a). Snails displaying a discontinuous apertural lip and a shell height of $70 \%$ or above than the average shell height of the collected adults were classified as 
subadult, whereas smaller snails were classified as juvenile.

After being photographed and measured, the shells were dissolved in EDTA (0.5 M, pH 7.5) for 3 days to expose the soft bodies. The snails were then dissected under a microscope to determine their sex (absence of a penis for females, Winterbourn, 1970b) and the presence of parasites. The number of embryos as proxy for fecundity was counted for each female by opening their brooding pouches (see Fig. 24A in Haase, 2008).

\section{Statistical analyses}

Univariate statistics were conducted to compare differences in shell height and environmental parameters among localities and differences in the number of brooded embryos among localities and age classes. Generalized linear models (GLMs), that allow for both continuous and categorical explanatory variables and do not require normally distributed errors of the response variables, were used to examine the influence of environmental parameters and the sampling month on the life history traits. The influence on shell height of adult snails $(N=614)$ was assessed with a linear model (LM). Collinearity between the explanatory

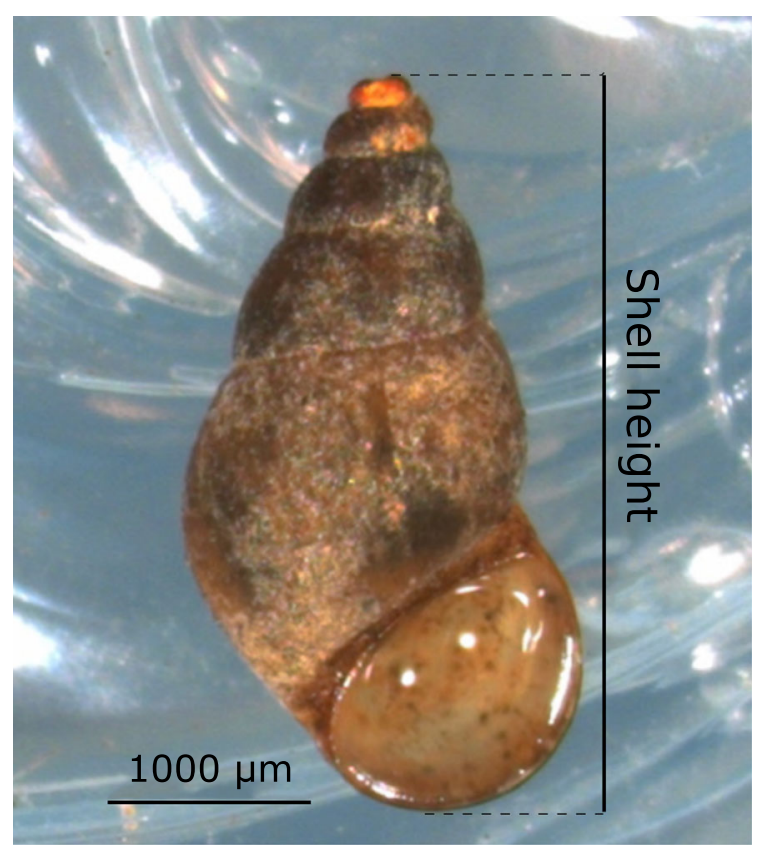

Fig. 2 Shell height of Potamopyrgus antipodarum. Adult individual collected in Jarmen in February 2017 variables was detected by calculating pairwise Goodman and Kruskal's tau (GK tau) measures, a method suited for both categorical and numerical variables, with the GKtauDataframe function implemented in the R package GoodmanKruskal v. 0.0.2 (Pearson, 2016). For pairs showing a strong association (GK tau values $\sim 1$ ), only one variable was maintained. The remaining explanatory variables tested in the model were as follows: month, temperature, salinity, and current. The influence on fecundity was tested with the same explanatory variables plus shell height with a GLM for Poisson-distributed errors. For this GLM, we only kept female adults brooding at least one embryo $(N=423)$ to meet the assumptions of the Poisson distribution.

The LM and the GLM were built with the lme 4 v. 1. 1-19 package in $\mathrm{R}$ (Bates et al., 2015) by stepwise dropping explanatory variables based on type-II Wald Chi-square tests of the Anova function implemented in the car package. The positive or negative effects of the final remaining significant explanatory variables were visualized by means of plots using the predictorEffects function (Fox \& Weisberg, 2018) of the effects v. 4.0-3 package (Fox, 2003). All statistical tests were executed in PAST v. 3.20 (Hammer et al., 2001) or in R v. 3.5.1 (R Core Team, 2013). Non-parametric tests were used if normal distributions were rejected by a Shapiro-Wilk test and $P$ values were Bonferroni corrected in case of multiple testing (e.g., pairwise tests).

\section{Results}

Variation in life history traits

A total of 1165 snails were collected between February 2017 and January 2018. Of these, 614 were adults, 403 were subadults, and 148 were juveniles. These three age classes were found all year around at least at one sampling location (Table 1). All dissected snails were females uninfected by parasites.

The shell height of adult snails varied between $2.2 \mathrm{~mm}$ (sampled in Rügen, February 2017) and $5.6 \mathrm{~mm}$ (Hohen Sprenz, December 2017), with an annual median size of $3.9 \mathrm{~mm}$. Significant differences in adults' shell height were found among three locations (Kruskal-Wallis $\quad C h i^{2}=356.3$, $P<0.0001$; pairwise Mann-Whitney $U$ tests 
summarized in Table 2), with the largest snails observed in Hohen Sprenz (median $=4.3 \mathrm{~mm}$ ), followed by Jarmen $(4.0 \mathrm{~mm})$ and Rügen $(3.5 \mathrm{~mm})$ (Fig. 3a). In a similar fashion, the shell height of the subadult snails varied significantly among locations $\left(C h i^{2}=189.9, P<0.0001\right.$; Table 2$)$, with the largest snails found in Hohen Sprenz (median $=3.9 \mathrm{~mm}$ ), followed by Jarmen $(3.6 \mathrm{~mm})$ and Rügen $(3.1 \mathrm{~mm})$. Brooding subadult snails ("with" embryos) were significantly larger (median $=3.8 \mathrm{~mm}$ ) compared to non-reproducing subadults ("without" embryos; $3.2 \mathrm{~mm} ; U=4590.5, P<0.0001)$. The size of brooding subadult snails varied again significantly among localities (Hohen Sprenz $=4.1 \mathrm{~mm}$, Jarmen $=3.8 \mathrm{~mm}, \quad$ Rügen $=3.4 \mathrm{~mm} ; \quad C h i^{2}=56.5$, $P<0.0001$; Table 2; Fig. 4).

The number of embryos brooded by adult snails varied between zero and 41 (Hohen Sprenz, September 2017) and between zero and 28 (Hohen Sprenz, December 2017) in subadults. Adult snails brooded significantly more embryos (median $=7$ ) compared to subadults (median $=0) \quad(U=68862, \quad P<0.0001)$. The annual total number of brooded embryos varied significantly among localities, both for adult $\left(\mathrm{Chi}^{2-}\right.$ $=204.7, P<0.0001)$ and subadult $\left(C h i^{2}=54.8\right.$, $P<0.0001)$ snails. The highest number of embryos was found in Hohen Sprenz (median adults $=14$, subadults $=6$ ), followed by Jarmen (adults $=9$, subadults $=0$ ) and Rügen (adults $=0$, subadults $=0$ ) (Table 3; Fig. 3b).
Table 2 Mann-Whitney $U$ and $P$ values for the pairwise comparisons of shell height between sampling locations

\begin{tabular}{ll}
\hline All adults & \\
Hohen Sprenz vs. Jarmen & $U=9503, P<0.0001$ \\
Hohen Sprenz vs. Rügen & $U=1227, P<0.0001$ \\
Jarmen vs. Rügen & $U=4417, P<0.0001$ \\
All subadults & $U=3122, P<0.0001$ \\
Hohen Sprenz vs. Jarmen & $U=1169, P<0.0001$ \\
Hohen Sprenz vs. Rügen & $U=3950, P<0.0001$ \\
Jarmen vs. Rügen & \\
Subadults with embryos & $U=638, P=0.007$ \\
Hohen Sprenz vs. Jarmen & $U=89, P<0.0001$ \\
Hohen Sprenz vs. Rügen & $U=99, P<0.0001$ \\
\hline Jarmen vs. Rügen &
\end{tabular}

Environmental and seasonal effects on life history traits

Water temperatures varied between 2.2 (Jarmen, February 2017) and $21.6^{\circ} \mathrm{C}$ (Hohen Sprenz, August 2017), with the coldest temperatures recorded between December and March $\left(6.1 \pm 2.1^{\circ} \mathrm{C}\right.$-mean $\left.\pm \mathrm{SD}\right)$ and the warmest between June and September $\left(18.8 \pm 2.9^{\circ} \mathrm{C}\right)$ (Fig. 5a). Potamopyrgus antipodarum were observed crawling at the bottom of the sampling locations throughout the year, including during the coldest months when the water surface was frozen. The annual mean water temperature was highest in Hohen Sprenz $\left(13.1 \pm 6.9^{\circ} \mathrm{C}\right)$, followed by Jarmen
Table 1 Number of snails collected monthly per age class at the three sampling locations between February 2017 and January 2018

\begin{tabular}{|c|c|c|c|c|c|c|c|c|c|}
\hline & \multicolumn{3}{|c|}{ Hohen Sprenz } & \multicolumn{3}{|c|}{ Jarmen } & \multicolumn{3}{|l|}{ Rügen } \\
\hline & Adult & Subadult & Juvenile & Adult & Subadult & Juvenile & Adult & Subadult & Juvenile \\
\hline Feb. & 7 & 2 & 1 & 21 & 1 & 0 & 11 & 6 & 12 \\
\hline Mar. & 21 & 4 & 6 & 14 & 1 & 0 & 12 & 10 & 2 \\
\hline Apr. & 18 & 5 & 1 & 21 & 6 & 0 & 27 & 29 & 7 \\
\hline May & 19 & 6 & 9 & 24 & 8 & 0 & 25 & 9 & 0 \\
\hline Jun. & 24 & 9 & 5 & 23 & 4 & 1 & 22 & 25 & 7 \\
\hline Jul. & 18 & 6 & 1 & 19 & 5 & 2 & 19 & 15 & 6 \\
\hline Aug. & 16 & 13 & 3 & 18 & 8 & 0 & 19 & 14 & 2 \\
\hline Sep. & 18 & 10 & 2 & 17 & 5 & 3 & 16 & 20 & 4 \\
\hline Nov. & 18 & 6 & 4 & 24 & 39 & 21 & 16 & 16 & 3 \\
\hline Dec. & 23 & 14 & 3 & 13 & 33 & 8 & 12 & 12 & 4 \\
\hline Jan. & 22 & 29 & 0 & 18 & 10 & 1 & 19 & 23 & 30 \\
\hline Total & 204 & 104 & 35 & 212 & 120 & 36 & 198 & 179 & 77 \\
\hline
\end{tabular}



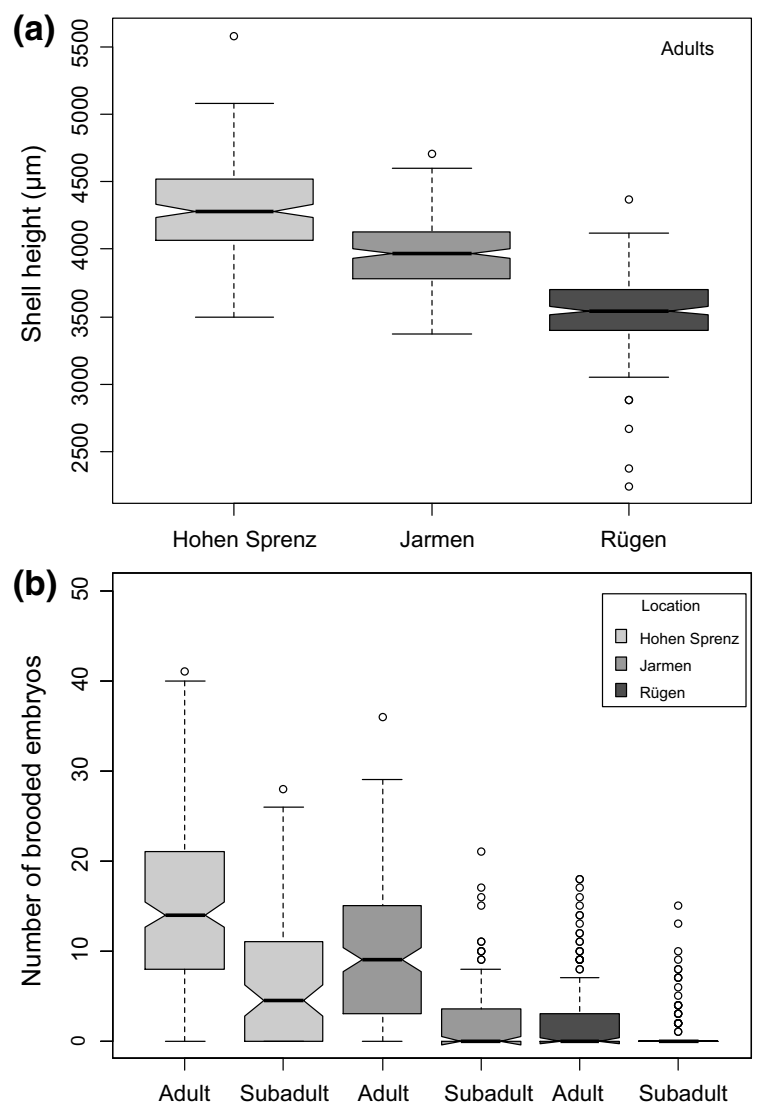

Fig. 3 Annual variation in shell height of adult females (a) and number of embryos brooded by adult and subadult females (b) among sampling location. Boxplots show the median (middle line), quartiles (boxes), 1.5 times the interquartile range (IQR) (whiskers), and extreme values (dots). Significant differences are illustrated by non-overlapping notches $( \pm 1.58$ times the IQR divided by the square root of the number of observations (Chambers et al., 1983))

$\left(12.2 \pm 6.8^{\circ} \mathrm{C}\right)$, and the lowest in Rügen $\left(11.7 \pm 4.0^{\circ} \mathrm{C}\right.$ ). Salinity varied between 130 (Hohen Sprenz, February 2017) and 379 ppm (Jarmen, September 2017), but showed no clear seasonal pattern (Fig. 5b). The annual mean salinity was the highest in Rügen $(287.3 \pm 36.1 \mathrm{ppm})$, followed by Jarmen (265 \pm 65.5), and the lowest in Hohen Sprenz (180.3 \pm 29.76).

Sampling month (Fig. 6), current, temperature, and salinity had significant effects both on shell height and the number of brooded embryos of adult snails (Fig. 7, Supplementary Fig. S2, Table 4). Temperature had a positive and salinity a negative effect on the snails' size and fecundity. Larger and more fecund snails were found in lentic sites compared to lotic ones.

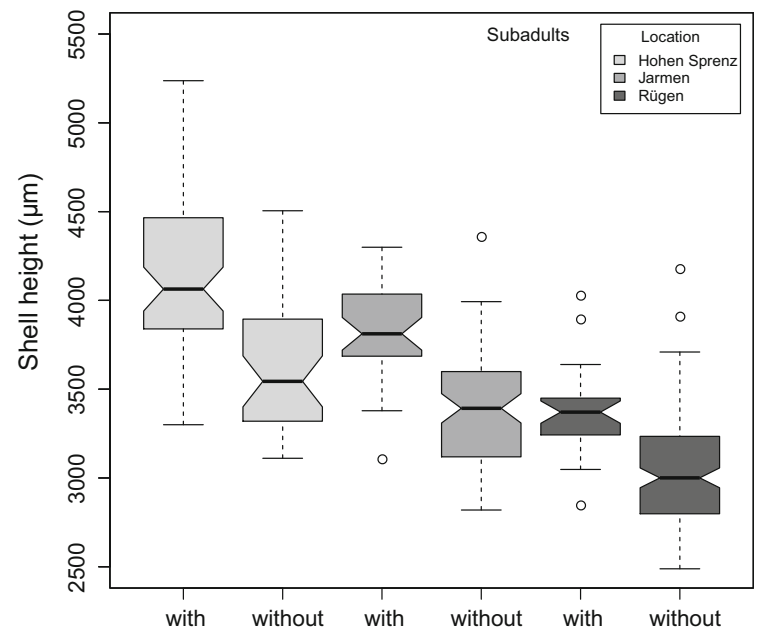

Fig. 4 Differences in shell height between subadult females that were brooding (with) or did not carry (without) embryos per sampling location. Boxplots show the median (middle line), quartiles (boxes), 1.5 times the interquartile range (IQR) (whiskers), and extreme values (dots). Significant differences are illustrated by non-overlapping notches

Table 3 Mann-Whitney $U$ and $P$ values for the pairwise comparisons of annual number of brooded embryos between sampling locations

\begin{tabular}{ll}
\hline Adults & \\
Hohen Sprenz vs. Jarmen & $U=14400, P=0.007$ \\
Hohen Sprenz vs. Rügen & $U=4869, P<0.0001$ \\
Jarmen vs. Rügen & $U=8774, P<0.0001$ \\
Subadults & \\
Hohen Sprenz vs. Jarmen & $U=3875, P<0.0001$ \\
Hohen Sprenz vs. Rügen & $U=4480, P<0.0001$ \\
Jarmen vs. Rügen & $U=8977, P<0.0001$ \\
\hline
\end{tabular}

Larger snails also brooded significantly more embryos. Overall, the shell size stayed relatively constant throughout the year, with a peak observed in winter during the months December through January, whereas fecundity was low from February to May, and high throughout the rest of the year, with a peak observed in June (and a second one in Hohen Sprenz in January; Figs. 6, 7). Monthly patterns in fecundity varied, however, among localities (Fig. 6). Adult snails were observed to brood embryos year-round in Hohen Sprenz and Jarmen, with a more pronounced increase toward summer in Jarmen, whereas brooding adults in Rügen were predominately found in summer 

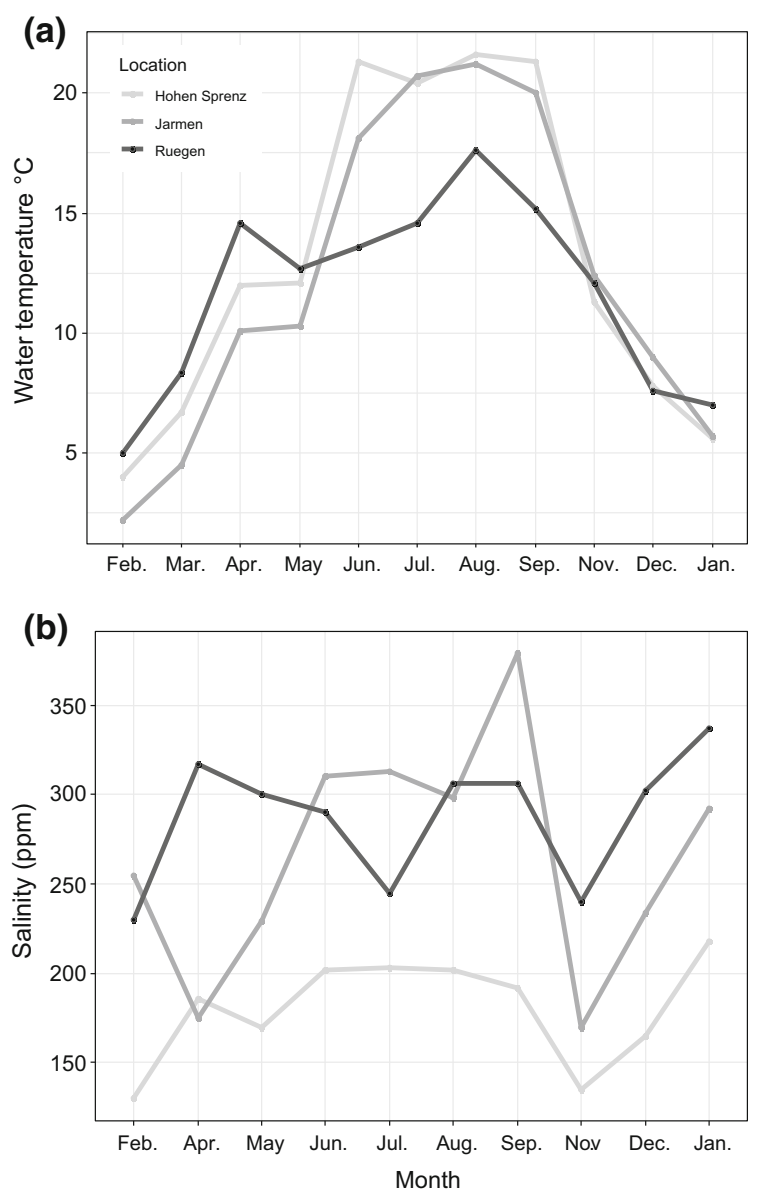

Fig. 5 Monthly variation in water temperature and salinity at the three sampling locations between February 2017 and January 2018

between June and September, but were nearly absent the rest of the year. In Hohen Sprenz, subadult snails showed a similar annual pattern compared to the adults, whereas in Jarmen and Rügen, the seasonal fecundity pattern was even more pronounced, with brooding occurring only from April to August in Jarmen, and half as long, from June to August, in Rügen.

\section{Discussion}

In order to explain the invasion success of $P$. antipodarum, we monitored shell size and fecundity of three of its Northeast German populations in monthly intervals over the course of one year. We found the following as expected: 1) drastic differences in space and time for these life history traits, and these differences were linked to specific environmental variables and 2) none of our dissected specimens to be infected by castrating parasites. Our expectation that invasive populations of $P$. antipodarum would be reproducing all year around was met at all but one sampling site, site Rügen, where it was seasonal.

\section{Environmental effects on life history traits}

Shell size and fecundity of adults varied among locations, despite the close relationship of the snails and their clonal nature (Verhaegen et al., 2018a). The observed variation was explained as response to specific environmental factors. The observed positive effect of temperature was in accordance with previous studies on size (Verhaegen et al., 2018b), growth rate (Dybdahl \& Kane, 2005), and fecundity (Dybdahl \& Kane, 2005; Gust et al., 2011; McKenzie et al., 2013; Verhaegen et al., 2018b). The positive effect of temperature on fecundity and size has, however, an upper limit following an optimum curve, as was experimentally shown (Macken et al., 2012; Bennett et al., 2015). The temperature range we measured $\left(2.2-21.6^{\circ} \mathrm{C}\right)$ was within the experimentally tested tolerance range of $0-28^{\circ} \mathrm{C}$ (Winterbourn, 1969; Hylleberg \& Siegismund, 1987; Bennett et al., 2015) and below the upper limit for fecundity (Macken et al., 2012) and growth (Bennett et al., 2015). Other annual temperatures measured in situ where living snails were found year-round ranged from 0 to $20^{\circ} \mathrm{C}$ in Denmark (Lumbye \& Lumbye, 1965), $2-19^{\circ} \mathrm{C}$ in a stream in Colorado (McKenzie et al., 2013), and from 11 to $23^{\circ} \mathrm{C}$ in an Australian lake (Schreiber et al., 1998). We collected living snails from the ice-covered lake in Jarmen in February 2017 at a water temperature of $2.2^{\circ} \mathrm{C}$. The collection of living snails from an icecovered lake at $1.5^{\circ} \mathrm{C}$ was so far only reported from the Netherlands (Dorgelo, 1987). However, survival rates apparently drop dramatically once temperatures drop below $0^{\circ} \mathrm{C}$ (Hylleberg \& Siegismund, 1987).

Salinity had a negative effect on the measured traits, which was in contrast to some of the previous studies. A negative effect on fecundity, but a positive effect on size were reported for native freshwater populations (Verhaegen et al., 2018b), whereas no effect was found in European brackish and freshwater populations (Verhaegen et al., 2018a). Herbst et al. (2008) experimentally showed a positive effect of 

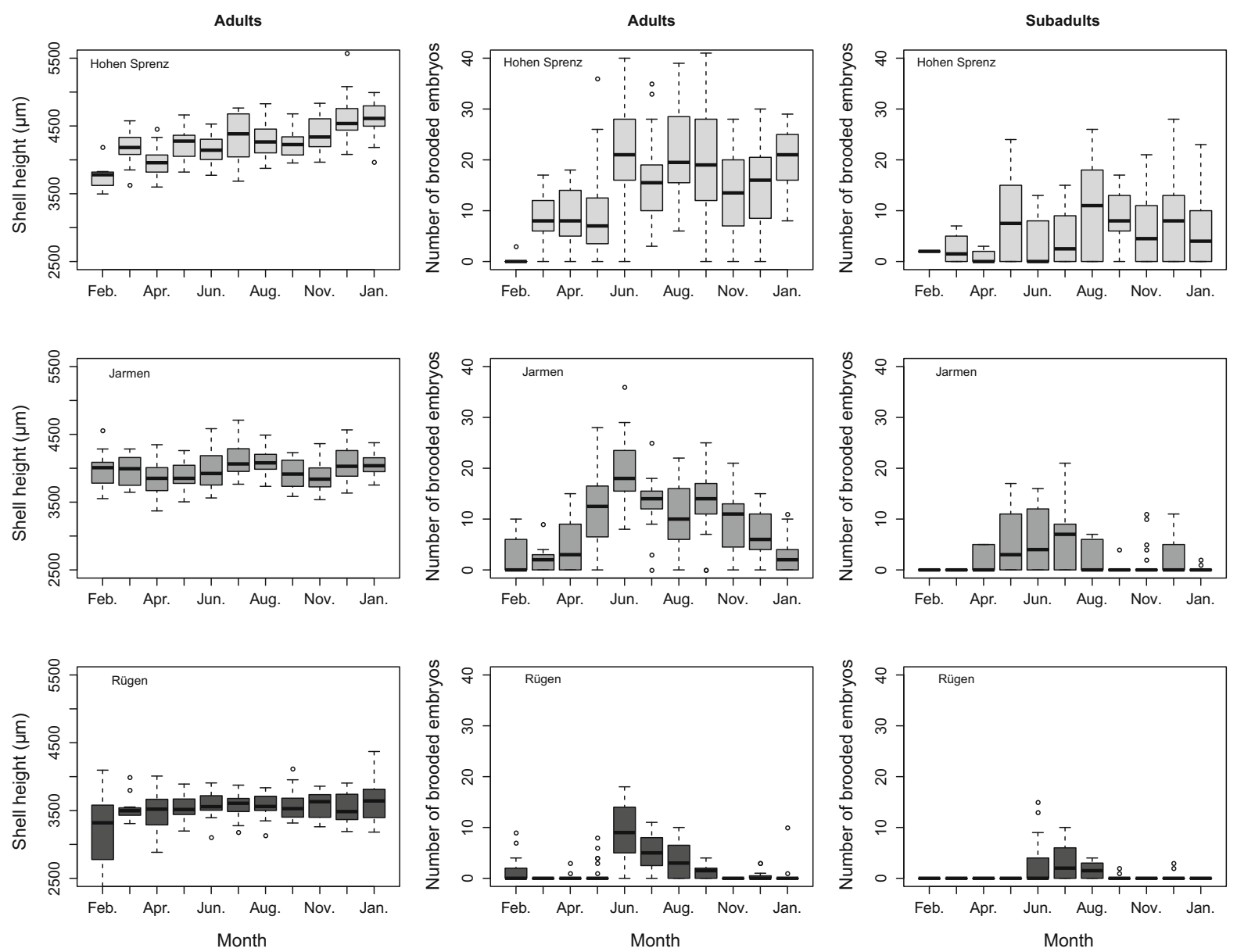

Fig. 6 Monthly variation in shell height of adult females and the number of brooded embryos carried by adult and subadult (middle line), quartiles (boxes), 1.5 times the interquartile range (IQR) (whiskers), and extreme values (dots) females among sampling locations. Boxplots show the median
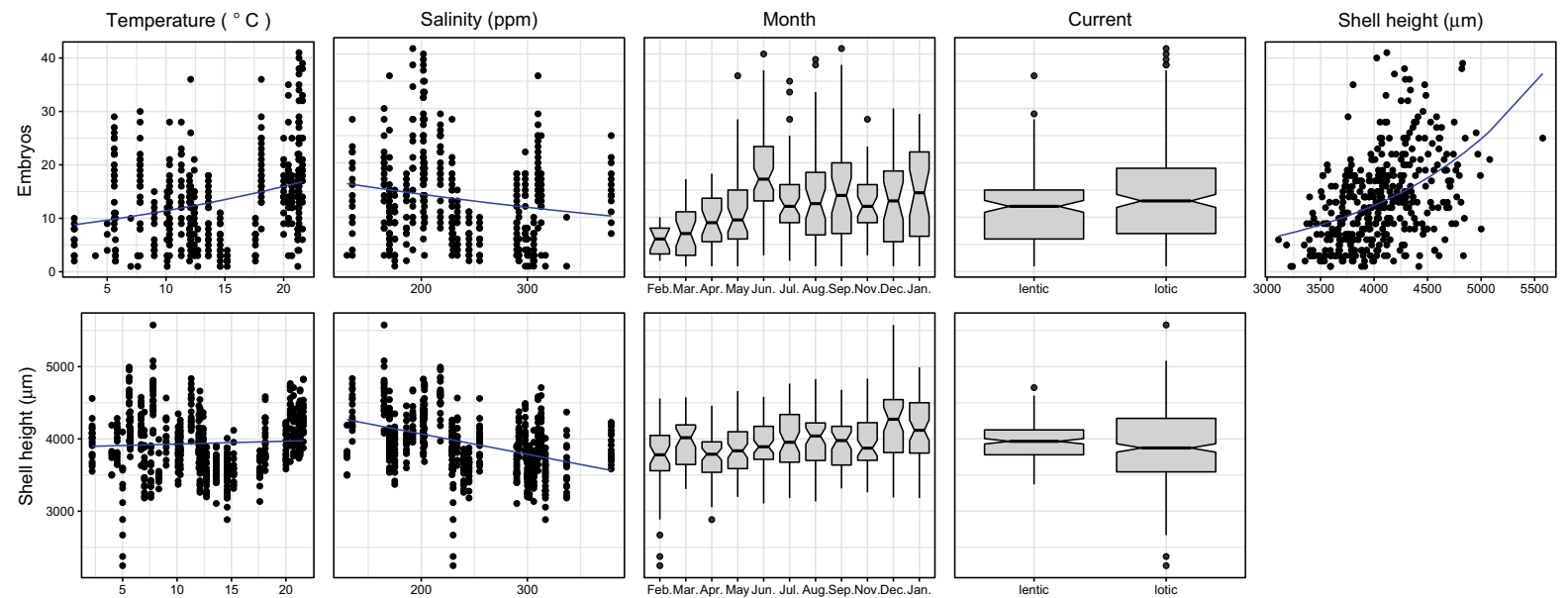

Fig. 7 Scatter plots and boxplots of shell height and the number of brooded embryos of adult females versus the explanatory variables that were found having a significant effect according to our (generalized) linear models 
Table 4 Coefficients of the two (generalized) linear models showing the effects of the significant explanatory variables on shell height and fecundity

Coefficients for the

categorical variables month and water type are related to the categories "February" and "lake", respectively

$S E$ standard error, $d f$ degrees of freedom

${ }^{\text {a }}$ Residual deviance (shell height): 54497128 on $554 d f$

${ }^{\mathrm{b}}$ Residual deviance (fecundity): 1199.2 on 380 $d f$

\begin{tabular}{|c|c|c|c|c|}
\hline & Estimate & SE & $t$ & $P$ \\
\hline \multicolumn{5}{|l|}{ Shell height $^{\mathrm{a}}$} \\
\hline Intercept & 4622.092 & 82.691 & 55.896 & $<0.0001$ \\
\hline Temperature & 43.802 & 6.877 & 6.369 & $<0.0001$ \\
\hline Month (April) & -278.810 & 89.626 & -3.111 & 0.002 \\
\hline Month (May) & -126.297 & 85.684 & -1.474 & 0.141 \\
\hline Month (June) & -209.206 & 118.595 & -1.764 & 0.078 \\
\hline Month (July) & -190.367 & 124.026 & -1.535 & 0.125 \\
\hline Month (Aug.) & -222.347 & 133.665 & -1.663 & 0.097 \\
\hline Month (Sep.) & -142.148 & 128.278 & -1.108 & 0.268 \\
\hline Month (Nov.) & -302.437 & 88.666 & -3.411 & 0.001 \\
\hline Month (Dec.) & 298.211 & 75.475 & 3.951 & $<0.0001$ \\
\hline Month (Jan.) & 575.485 & 69.515 & 8.279 & $<0.0001$ \\
\hline Water type (stream) & -193.057 & 28.687 & -6.730 & $<0.0001$ \\
\hline Salinity & -4.322 & 0.251 & -17.239 & $<0.0001$ \\
\hline \multicolumn{5}{|l|}{ Fecundity $^{\mathrm{b}}$} \\
\hline Intercept & -0.044 & 0.274 & -0.162 & 0.872 \\
\hline Shell height & 0.001 & 0.000 & 13.396 & $<0.0001$ \\
\hline Temperature & 0.042 & 0.009 & 4.537 & $<0.0001$ \\
\hline Month (April) & -0.032 & 0.145 & -0.218 & 0.827 \\
\hline Month (May) & 0.233 & 0.142 & 1.644 & 0.100 \\
\hline Month (Jun.) & 0.586 & 0.196 & 2.995 & 0.003 \\
\hline Month (July) & 0.074 & 0.200 & 0.368 & 0.713 \\
\hline Month (Aug.) & 0.101 & 0.211 & 0.481 & 0.631 \\
\hline Month (Sep.) & 0.311 & 0.209 & 1.488 & 0.137 \\
\hline Month (Nov.) & 0.030 & 0.140 & 0.213 & 0.831 \\
\hline Month (Dec.) & 0.179 & 0.128 & 1.399 & 0.162 \\
\hline Month (Jan.) & 0.553 & 0.126 & 4.386 & $<0.0001$ \\
\hline Water type (stream) & -0.183 & 0.045 & -4.032 & $<0.0001$ \\
\hline Salinity & -0.003 & 0.000 & -6.463 & $<0.0001$ \\
\hline
\end{tabular}

Sprenz (a stream) and Rügen (a spring), being much smaller compared to the lentic site Jarmen (a lake). Indeed, Verhaegen et al. (2018b) showed the largest $P$. antipodarum to be found in lakes and large streams, the size to decrease with stream size, and the smallest snails to be found in springs. The effects of temperature, salinity, and water body type we observed explain why the smallest and less fecund individuals were found in Rügen, a small spring where the coldest annual temperatures and highest annual salinities were recorded. The lower fecundity was shown for lotic habitats before (Verhaegen et al., 2018a) and likely represents a trade-off with living in habitats where more resources have to be allocated to fight 
dislodgment risk due to increased drag and lift forces (Verhaegen et al., 2019).

The shell size of adult snails had a positive effect on the number of embryos they brooded, as demonstrated previously (McKenzie et al., 2013; Verhaegen et al., 2018a, b). As expected, the size of brooding subadults varied also significantly among locations. Female size at maturity was already known to vary among native populations (Jokela et al., 1997), early reproduction being hypothesized to be a response against high parasitic pressures (Jokela \& Lively, 1995). Here, in the invaded range, size of both adult and brooding subadult snails was the smallest in Rügen. This sampling location obviously provided the least favorable environmental conditions for both size and fecundity (see above). By modifying the size at sexual maturity, $P$. antipodarum appears to ensure reproduction also in less suitable habitats not supporting large body size, however, at the cost of smaller brood size. Early sexual maturity is also known to be another life history trait favoring the range expansion success of invasive species [e.g., in invasive pines (Richardson et al., 1990)]. We, therefore, suggest early sexual maturity and the adaptation of size at sexual maturity to be added to the list of functional traits explaining the invasive success of $P$. antipodarum (Alonso \& CastroDíez, 2008).

The adaptation of life history traits to changing environments has been a key feature in the range expansion success of invasive species (e.g., Dlugosch \& Parker, 2008; Jaspers et al., 2014; Li et al., 2015). Any forms of adaptation can be mediated through natural selection of beneficial alleles or genotypes introduced into a population through mutation, migration, or recombination (Carja et al., 2014), and/or by phenotypic plasticity (Sultan, 1995). In the case of asexual species or lineages reproducing without recombination, which is the case for the ameiotic parthenogenetic invasive lineages of $P$. antipodarum, the adaptation of life history traits as observed here, should mostly be the result of phenotypic plasticity (e.g., Verhaegen et al., 2018a, b). Besides the measured environmental parameters, other biotic factors and pollutants are also known to influence life history traits in P. antipodarum. For instance, fecundity can be affected by population density (e.g., Neiman et al., 2013; Zachar \& Neiman, 2013) or anthropogenic chemicals interfering with reproductive endocrinology (e.g., Duft et al., 2003; Jobling et al.,
2003; Geiß et al., 2017). Therefore, it would be interesting to extend this study and test the effect of additional factors on the variability of plasticity in life history traits.

\section{Temporal fluctuations}

Size, represented by shell height, and fecundity were also significantly affected by the sampling month. The size of adult snails slightly increased throughout the year to reach a peak in January (Fig. 7). In Denmark, however, a seasonal increase in average weight of unspecified age class was reported toward the summer months (Lumbye \& Lumbye, 1965), but the annual variation in shell size was not investigated before. Annual fecundity patterns of adults and subadults varied among locations. At two of our three locations, adult snails brooded embryos year-round. In Rügen, however, brooding adults were almost only found during the warmest months, from June to September. In the literature, adult snails are usually reported to brood throughout the year [e.g., in New Zealand (Winterbourn, 1970a) and in the USA (McKenzie et al., 2013)], with the exception of an Australian site where brooding adults were absent in one month (Schreiber et al., 1998). This is, thus, the first report of a population that does not reproduce throughout most of the year. The number of brooded embryos by adults and subadults varied seasonally, in concordance with what was found on other continents (Winterbourn, 1970a; Schreiber et al., 1998; McKenzie et al., 2013). The duration of the period of maximum fecundity varied, however, among locations and age classes. Adults showed a longer high-reproductive season than subadults, and this high-reproductive season of adult snails from Hohen Sprenz was twice as long compared to that on Rügen lasting from June to January. A less pronounced seasonality in the life history traits such as growth rate and reproduction is obvious at sites with a more benign climate year-round (Bennett et al., 2015). We observed juveniles throughout the year at least at one of the three sites. The occasional absence in our collections was probably due to our sampling method. Year-round recruitment in this species has been shown both in the native (Winterbourn, 1970a) and invaded ranges (Schreiber et al., 1998; Bennett et al., 2015). Although not investigated in this study, it is important to note that densities of $P$. antipodarum have also been reported to fluctuate through time and among localities 
(e.g., Lumbye \& Lumbye, 1965; Dorgelo, 1987; Schreiber et al., 1998; Bennett et al., 2015) and can influence the growth rate and fecundity in P. antipodarum as well (e.g., Neiman, 2006; Neiman et al., 2013; Sieratowicz et al., 2013; Zachar \& Neiman, 2013).

Sex and parasitism in the invaded range

All dissected snails were females and none were infected by parasites. This is what is typically found in the invaded range of $P$. antipodarum. Previous studies found no infected snails $(N=425)$ in Belgium, Germany, or the Netherlands (Verhaegen et al., 2018a), an 0.01-0.02\% infection rate in Poland (Zbikowski \& Zbikowska, 2009; Cichy et al., 2017), 0-0.10\% in the USA (Adema et al., 2009; McKenzie et al., 2013), 0.22-0.48\% in France (Gérard \& Dussart, 2003; Gérard \& Le Lannic, 2003; Gérard et al., 2003), $1.33 \%$ in the United Kingdom (UK) (Evans et al., 1981), and 3.6\% in an Australian lake (Schreiber et al., 1998). The presence of males in the invaded range is even rarer: although the percentage of males in Europe ranged from zero to $5 \%$ in earlier studies (Wallace, 1985), no males were recently reported in Belgium, Germany, the Netherlands, Poland, and the USA (Cichy et al., 2017; McKenzie et al., 2013; Verhaegen et al., 2018a), only one male individual out of 5,774 was found in France (Gérard et al., 2003), and 1.1\% of males were found in Australia (Schreiber et al., 1998). Our observations support yet another factor explaining the invasive success of $P$. antipodarum: the combination of the "Enemy release" and the ability to reproduce parthenogenetically (Lively, 1992).

\section{Conclusion}

The processes that lead to a successful invasion are complex. In situations where natural predators are lacking, a competitive invader is determined by specific r-strategy life history traits (e.g., fast growth, high reproduction) and phenotypic plasticity (Sax \& Brown, 2000; Facon et al., 2006; Sorte et al., 2010). An additional advantage is given to invaders that reproduce asexually or self-fertilize and are, therefore, not limited by the difficulties of finding a mate at the early stages of colonization (Tobin et al., 2011). Here, we characterized the growth and reproduction of such an asexually reproducing invader, $P$. antipodarum, by monitoring monthly, over the course of a year, shell height and number of brooded embryos in three Northeast German populations. Castrating parasites are typically lacking in its invaded range and were absent as well from all our dissected specimens. Our expectation that $P$. antipodarum would reproduce all year around, which was observed for other invaded continents (Schreiber et al., 1998; McKenzie et al., 2013) and the native range (Winterbourn, 1970a), was only met at two of our three monitored sampling sites. Brooding females at the small spring brook site Rügen were only found predominantly during the summer months. As expected, however, we found drastic differences in adult size, size at sexual maturity, and fecundity among sampling locations and over time, despite the high genetic similarity of these clonal lineages (Verhaegen et al., 2018a) and the small geographical scale. The observed spatial and temporal variation of these life history traits was obviously due to adaptation to the differing local habitat conditions and most likely an environment-induced plastic response. Together with ovoviviparity and the ability to reproduce parthenogenetically while being released from parasite pressure, the ability to adapt readily to a wide range of habitat conditions is likely paramount for the invasive success of $P$. antipodarum.

Acknowledgements We thank D. Treschnak, S. Fregin, and N. Lieker for their assistance with fieldwork. G. Uhl is thanked for providing access to the Zeiss microscope. We are grateful to W. Matzke of the Biosphärenreservatsamt Südost-Rügen for providing a collecting permit. We also thank G. Collado and two anonymous reviewers for their constructive comments on previous versions of the manuscript. This study was conducted in the frame of the Research Training Group 2010 RESPONSE funded by the Deutsche Forschungsgemeinschaft (DFG). Open Access funding provided by Projekt DEAL.

Open Access This article is licensed under a Creative Commons Attribution 4.0 International License, which permits use, sharing, adaptation, distribution and reproduction in any medium or format, as long as you give appropriate credit to the original author(s) and the source, provide a link to the Creative Commons licence, and indicate if changes were made. The images or other third party material in this article are included in the article's Creative Commons licence, unless indicated otherwise in a credit line to the material. If material is not included in the article's Creative Commons licence and your intended use is not permitted by statutory regulation or exceeds the permitted use, you will need to obtain permission directly from the copyright holder. To view a copy of this licence, visit http://creativecommons.org/licenses/by/4.0/. 
Author contributions $\mathrm{GV}$ and $\mathrm{MH}-$ Fieldwork. KvJDissections and measurements. GV, MH, and KvJ-Statistical analyses. GV, MH, and KvJ-Manuscript; GV and MH-Study concept and experimental design

\section{References}

Adema, C. M., C.-M. Lun, B. Hanelt \& R. S. Seville, 2009. Digenean trematode infections of native freshwater snails and invasive Potamopyrgus antipodarum in the Grand Teton National Park/John D. Rockefeller Memorial Parkway Area. Journal of Parasitology 95: 224-227.

Alonso, Á. \& P. Castro-Díez, 2008. What explains the invading success of the aquatic mud snail Potamopyrgus antipodarum (Hydrobiidae, Mollusca)? Hydrobiologia 614: 107-116.

Alonso, Á. \& P. Castro-Díez, 2012. The exotic aquatic mud snail Potamopyrgus antipodarum (Hydrobiidae, Mollusca): state of the art of a worldwide invasion. Aquatic Sciences 74: 375-383.

Bates, D., M. Mächler, B. Bolker \& S. Walker, 2015. Fitting Linear Mixed-Effects Models using lme4. Journal of Statistical Software 67: 1-48.

Bell, G., 1982. The Masterpiece of Nature: The Evolution and Genetics of Sexuality. CUP Archive.

Bennett, D. M., T. L. Dudley, S. D. Cooper \& S. S. Sweet, 2015. Ecology of the invasive New Zealand mud snail, Potamopyrgus antipodarum (Hydrobiidae), in a mediterraneanclimate stream system. Hydrobiologia 746: 375-399.

Caraco, N. F., J. J. Cole, P. A. Raymond, D. L. Strayer, M. L. Pace, S. E. Findlay \& D. T. Fischer, 1997. Zebra mussel invasion in a large, turbid river: phytoplankton response to increased grazing. Ecology 78: 588-602.

Carja, O., U. Liberman \& M. W. Feldman, 2014. Evolution in changing environments: modifiers of mutation, recombination, and migration. Proceedings of the National Academy of Sciences of the United States of America 111: 17935-17940.

Chambers, J. M., W. S. Cleveland, B. Kleiner, \& P. A. Tukey, 1983. Graphical methods for data analysis. Wadsworth \& Brooks. Cole Statistics/Probability Series.

Cichy, A., A. Marszewska, J. Parzonko, J. Żbikowski \& E. Żbikowska, 2017. Infection of Potamopyrgus antipodarum (Gray, 1843) (Gastropoda: Tateidae) by trematodes in Poland, including the first record of aspidogastrid acquisition. Journal of Invertebrate Pathology 150: 32-34.

Collado, G. A., 2014. Out of New Zealand: molecular identification of the highly invasive freshwater mollusk Potamopyrgus antipodarum (Gray, 1843) in South America. Zoological Studies 53: 1-9.

Collado, G. A., K. P. Aguayo, N. J. Cazzaniga, D. E. Gutiérrez Gregoric, M. De Lucía \& M. Haase, 2019a. Systematic evaluation of cryptic freshwater snails from central Chile, including the enigmatic Littoridina santiagensis (Gastropoda, Truncatelloidea). European Journal of Taxonomy 524: $1-15$.
Collado, G. A., M. A. Vidal, K. P. Aguayo, M. A. Méndez, M. A. Valladares, F. J. Cabrera, L. Pastenes, D. E. Gutiérrez Gregoric \& N. Puillandre, 2019b. Morphological and molecular analysis of cryptic native and invasive freshwater snails in Chile. Scientific Reports 9: 1-11.

Darwin, C., 1859. On the Origin of Species by Means of Natural Selection. Routledge, Cambridge.

Dlugosch, K. M. \& I. M. Parker, 2008. Invading populations of an ornamental shrub show rapid life history evolution despite genetic bottlenecks. Ecology Letters 11: 701-709.

Dorgelo, J., 1987. Density fluctuations in populations (19821986) and biological observations of Potamopyrgus jenkinsi in two trophically differing lakes. Hydrobiological Bulletin 21: 95-110.

Duft, M., U. Schulte-Oehlmann, M. Tillmann, B. Markert \& J. Oehlmann, 2003. Toxicity of triphenyltin and tributyltin to the freshwater mudsnail Potamopyrgus antipodarum in a new sediment biotest. Environmental Toxicology and Chemistry 22: 145-152.

Dybdahl, M. F. \& S. L. Kane, 2005. Adaptation vs. phenotypic plasticity in the success of a clonal invader. Ecological Society of America 86: 1592-1601.

Dybdahl, M. F. \& C. M. Lively, 1995. Diverse, endemic and polyphyletic clones in mixed populations of a freshwater snail (Potamopyrgus antipodarum). Journal of Evolutionary Biology 8: 385-398.

Eriksen, R. L., T. Desronvil, J. L. Hierro \& R. Kesseli, 2012. Morphological differentiation in a common garden experiment among native and non-native specimens of the invasive weed yellow starthistle (Centaurea solstitialis). Biological Invasions 14: 1459-1467.

Evans, N. A., P. J. Whitfield \& A. P. Dobson, 1981. Parasite utilization of a host community: the distribution and occurrence of metacercarial cysts of Echinoparyphium recurvatum (Digenea: Echinostomatidae) in seven species of mollusc at Harting Pond, Sussex. Parasitology 83: 1-12.

Facon, B., B. J. Genton, J. Shykoff, P. Jarne, A. Estoup \& P. David, 2006. A general eco-evolutionary framework for understanding bioinvasions. Trends in Ecology and Evolution 21: 130-135.

Fox, J., 2003. Effect displays in R for generalised linear models. Journal of statistical software 8: 1-27.

Fox, J. \& S. Weisberg, 2018. Visualizing fit and lack of fit in complex regression models with predictor effect plots and partial residuals. Journal of Statistical Software 87: 1-27.

Gangloff, M. M., 1998. The New Zealand mud snail in Western North America. Aquatic Nuisance Species 2: 25-30.

Geiß, C., K. Ruppert, C. Askem, C. Barroso, D. Faber, V. Ducrot,... \& L. Lagadic, 2017. Validation of the OECD reproduction test guideline with the New Zealand mudsnail Potamopyrgus antipodarum using trenbolone and prochloraz. Ecotoxicology 26: 370-382.

Gérard, C, \& G. B. J. Dussart, 2003. Invader and invadedcolonisation by, and of, Potamopyrgus antipodarum Gray (Mollusca, Hydrobiidae). In BCPC Symposium Proceedings No 80, Slugs \& Snails: Agricultural, Veterinary \& Environmental Perspectives: 281-286.

Gérard, C. \& J. Le Lannic, 2003. Establishment of a new hostparasite association between the introduced invasive species Potamopyrgus antipodarum (Smith) (Gastropoda) and 
Sanguinicola sp. Plehn (Trematoda) in Europe. Journal of Zoology 261: 213-216.

Gérard, C., A. Blanc \& K. Costil, 2003. Potamopyrgus antipodarum (Mollusca:Hydrobiidae) in continental aquatic gastropod communities: Impact of salinity and trematode parasitism. Hydrobiologia 493: 167-172.

Gérard, C., O. Miura, J. Lorda, T. H. Cribb, M. J. Nolan \& R. F. Hechinger, 2017. A native-range source for a persistent trematode parasite of the exotic New Zealand mudsnail (Potamopyrgus antipodarum) in France. Hydrobiologia 785: 115-126.

Gerritsen, J., 1980. Sex and parthenogenesis in sparse populations. The American Naturalist 115: 718-742.

Gibson, A. K., L. F. Delph \& C. M. Lively, 2017. The two-fold cost of sex: experimental evidence from a natural system. Evolution Letters 1: 6-15.

Goldschmidt, T., 1996. Darwin's Dreampond: Drama in Lake Victoria. MIT Press, Cambridge.

Gust, M., T. Buronfosse, C. André, R. Mons, F. Gagné \& J. Garric, 2011. Is exposure temperature a confounding factor for the assessment of reproductive parameters of New Zealand mudsnails Potamopyrgus antipodarum (Gray)? Aquatic Toxicology 101: 396-404.

Haase, M., 2003. Clinal variation in shell morphology of the freshwater gastropod Potamopyrgus antipodarum along two hill-country streams in New Zealand. Journal of the Royal Society of New Zealand 33: 549-560.

Haase, M., 2008. The radiation of hydrobiid gastropods in New Zealand: a revision including the description of new species based on morphology and mtDNA sequence information. Systematics and Biodiversity 6: 99-159.

Hall Jr., O., J. L. K. Robert \& M. F. Dybdahl, 2003. Exotic snails dominate nitrogen and carbon cycling in a highly productive stream. Frontiers in Ecology and the Environment 1: $407-411$.

Hammer, Ø., D. A. T. Harper \& P. D. Ryan, 2001. PASTpalaeontological statistics. Paleontologia Electronica 4: $1-9$.

Hauser, L., G. R. Carvalho, R. N. Hughes \& R. E. Carter, 1992. Clonal structure of the introduced freshwater snail Potamopyrgus antipodarum (Prosobranchia: Hydrobiidae), as revealed by DNA fingerprintring. Proceedings of the Royal Society B 249: 19-25.

Hechinger, R. F., 2012. Faunal survey and identification key for the trematodes (Platyhelminthes: Digenea) infecting Potamopyrgus antipodarum (Gastropoda: Hydrobiidae) as first intermediate host. Zootaxa 27: 1-27.

Herbst, D. B., M. T. Bogan \& R. A. Lusardi, 2008. Low specific conductivity limits growth and survival of the New Zealand mud snail from the Upper Owens River, California. Western North American Naturalist 68: 324-333.

Hughes, R. N., 1996. Evolutionary ecology of parthenogenetic strains of the prosobranch snail, Potamopyrgus antipodarum $($ Gray $)=P$. jenkinsi (Smith). Malacological Review 28: 101-114.

Hylleberg, J. \& H. R. Siegismund, 1987. Niche overlap in mud snails (Hydrobiidae): freezing tolerance. Marine Biology 94: 403-407.

Jacobsen, R., V. E. Forbes \& O. Skovgaard, 1996. Genetic population structure of the prosobranch snail Potamopyrgus antipodarum (Gray) in Denmark using PCR-RAPD fingerprints. Proceedings. Biological sciences/The Royal Society 263: 1065-1070.

Jain, S. K., 1976. The evolution of inbreeding in plants. Annual Review of Ecology and Systematics 7: 469-495.

Jaspers, C., L. F. Møller \& T. Kiørboe, 2014. Reproduction rates under variable food conditions and starvation in Mnemiopsis leidyi: significance for the invasion success of a ctenophore. Journal of Plankton Research 37: 1011-1018.

Jobling, S., D. Casey, T. Rodgers-Gray, J. Oehlmann, U. Schulte-Oehlmann, S. Pawlowski, T. Baunbeck, A. P. Turner \& C. R. Tyler, 2003. Comparative responses of molluscs and fish to environmental estrogens and an estrogenic effluent. Aquatic Toxicology 65: 205-220.

Jokela, J. \& C. M. Lively, 1995. Parasites, sex, and early reproduction in a mixed population of freshwater snails. Evolution 49: 1268-1271.

Jokela, J., C. M. Lively, M. F. Dybdahl \& J. A. Fox, 1997. Evidence for a cost of sex in the freshwater snail Potamopyrgus antipodarum. Ecology 78: 452-460.

Jokela, J., M. F. Dybdahl \& C. M. Lively, 2009. The maintenance of sex, clonal dynamics, and host-parasite coevolution in a mixed population of sexual and asexual snails. The American Naturalist 174: S43-S53.

Kerans, B. L., M. F. Dybdahl, M. M. Gangloff \& J. E. Jannot, 2005. Potamopyrgus antipodarum: distribution, density, and effects on native macroinvertebrate assemblages in the Greater Yellowstone ecosystem. Journal of the North American Benthological Society 24: 123-138.

Kistner, E. J. \& M. F. Dybdahl, 2013. Adaptive responses and invasion: the role of plasticity and evolution in snail shell morphology. Ecology and Evolution 3: 424-436.

Lassen, H. H., 1979. Reproductive effort in Danish mudsnails (Hydrobiidae). Oecologia 40: 365-369.

Laverty, C., W. Nentwig, J. T. A. Dick \& F. E. Lucy, 2015. Alien aquatics in europe: assessing the relative environmental and socioeconomic impacts of invasive aquatic macroinvertebrates and other taxa. Management of Biological Invasions 6: 341-350.

Leclair, L. L. \& Y. W. Cheng, 2011. A review of salinity tolerances for the New Zealand Mudsnail (Potamopyrgus antipodarum, Gray 1843) and the Effect of a Controlled Saltwater Backflush on their Survival in an Impounded Freshwater Lake. Journal of Shellfish Research 30: 905-914.

Levri, E. P., A. C. Krist, R. Bilka \& M. F. Dybdahl, 2014. Phenotypic plasticity of the introduced New Zealand mud snail, Potamopyrgus antipodarum, compared to sympatric native snails. PLoS ONE 9: e93985.

Lewin, I. \& A. Smoliński, 2006. Rare and vulnerable species in the mollusc communities in the mining subsidence reservoirs of an industrial area (The Katowicka Upland, Upper Silesia, Southern Poland). Limnologica 36: 181-191.

Li, X. M., D. Y. She, D. Y. Zhang \& W. J. Liao, 2015. Life history trait differentiation and local adaptation in invasive populations of Ambrosia artemisiifolia in China. Oecologia 177: 669-677.

Lively, C. M., 1992. Parthenogenesis in a fresh-water snailreproductive assurance versus parasitic release. Evolution 46: 907-913. 
Lloyd, D. G., 1979. Some reproductive factors affecting the selection of self-fertilization in plants. The American Naturalist 113: 67-79.

Lumbye, J. \& L. E. Lumbye, 1965. The oxygen consumption of Potamopyrgus jenkinsi (Smith). Hydrobiologia 25: 489-500.

Lysne, S. \& P. Koetsier, 2006. Experimental studies on habitat preference and tolerances of three species of snails from the Snake River of southern Idaho. American Malacological Bulletin 21: 77-85.

Macken, A., G. Le Page, A. Hayfield, T. D. Williams \& R. J. Brown, 2012. Effects of test design and temperature in a partial life-cycle study with the freshwater gastropod $\mathrm{Po}$ tamopyrgus antipodarum. Environmental Toxicology and Chemistry 31: 1989-1994.

Maynard Smith, J., 1971. The origin and maintenance of sex. Group selection, Chicago.

McCann, S., M. J. Greenlees, D. Newell \& R. Shine, 2014. Rapid acclimation to cold allows the cane toad to invade montane areas within its Australian range. Functional Ecology 28: 1166-1174.

McKenzie, V. J., W. E. Hall \& R. P. Guralnick, 2013. New Zealand mudsnails (Potamopyrgus antipodarum) in Boulder Creek, Colorado: environmental factors associated with fecundity of a parthenogenic invader. NRC Research Press 36: 30-36.

Múrria, C., N. Bonada \& N. Prat, 2008. Effects of the invasive species Potamopyrgus antipodarum (Hydrobiidae, Mollusca) on community structure in a small Mediterranean stream. Fundamental and Applied Limnology 171: 131-143.

Neiman, M., 2006. Embryo production in a parthenogenetic snail (Potamopyrgus antipodarum) is negatively affected by the presence of other parthenogenetic females. Invertebrate Biology 125: 45-50.

Neiman, M. \& B. Koskella, 2009. Chapter 7 - Sex and the Red Queen Lost sex. Springer, Dordrecht: 133-159.

Neiman, M., D. Warren, B. Rasmussen, S. Zhang \& S. Zhang, 2013. Complex consequences of increased density for reproductive output in an invasive freshwater snail. Evolutionary ecology 27: 1117-1127.

Neiman, M., C. M. Lively \& S. Meirmans, 2017. Why sex? A pluralist approach revisited. Trends in Ecology and Evolution Elsevier Ltd 32: 589-600.

Neiman, M., D. Paczesniak, D. M. Soper, A. T. Baldwin \& G. Hehman, 2011. Wide variation in ploidy level and genome size in a New Zealand freshwater snail with coexisting sexual and asexual lineages. Evolution 65: 3202-3216.

Nentwig, W., 2007. Biological Invasions: Why It Matters Biological Invasions. Springer, Berlin Heidelberg: 1-6.

Nentwig, W., S. Bacher, S. Kumschick, P. Pyšek \& M. Vilà, 2018. More than " 100 worst" alien species in Europe. Biological Invasions 20: 1611-1621.

Pearson, R., 2016. GoodmanKruskal: association analysis for categorical variables. $\mathrm{R}$ package.

Pimentel, D., L. Lach, R. Zuniga \& D. Morrison, 2006. Environmental and economic costs of nonindigenous species in the United States. BioScience 50: 53.

R Core Team, 2013. R: A language and environment for statistical computing. Vienna, http://www.r-project.org/.
Real, G., 1971. Ecologie et cycle de la ponte dans la région d'Arcachon de Potamopyrgus jenkinsi. Haliotis 1: 49-50.

Richards, D. C., 2004. Competition between the threatened Bliss Rapids snail, Taylorconcha serpenticola (Hershler et al.) and the invasive, aquatic snail, Potamopyrgus antipodarum (Gray). PhD Dissertation. Montana State University.

Richards, D. C., P. O'Connell \& D. C. Shinn, 2004. Simple control method to limit the spread of the New Zealand mudsnail Potamopyrgus antipodarum. North American Journal of Fisheries Management 24: 114-117.

Richardson, D. M., R. M. Cowling \& D. C. Le Maitre, 1990. Assessing the risk of invasive success in Pinus and Banksia in South African mountain fynbos. Journal of Vegetation Science 1: 629-642.

Riley, L. A., M. F. Dybdahl \& R. O. Hall Jr., 2008. Invasive species impact: asymmetric interactions between invasive and endemic freshwater snails. Journal of the North American Benthological Society 27: 509-520.

Sakai, A. K., F. W. Allendorf, J. S. Holt, D. M. Lodge, J. Molofsky, K. A. With, S. Baughman, R. J. Cabin, J. E. Cohen, N. C. Ellstrand, D. E. Mccauley, P. O. Neil, I. M. Parker, J. N. Thompson \& S. G. Weller, 2001. The population biology of invasive species. Annual Review of Ecology and Systematics 32: 305-332.

Sax, D. F. \& J. H. Brown, 2000. The paradox of invasion. Global Ecology and Biogeography 9: 363-371.

Schmidlin, S., D. Schmera \& B. Baur, 2012. Alien molluscs affect the composition and diversity of native macroinvertebrates in a sandy flat of Lake Neuchâtel, Switzerland. Hydrobiologia 679: 233-249.

Schreiber, E. S. G., A. Glaister, G. P. Quinn \& P. S. Lake, 1998. Life history and population dynamics of the exotic snail Potamopyrgus antipodarum (Prosobranchia:Hydrobiidae) in Lake Purrumbete, Victoria, Australia. Marine \& Freshwater Research 49: 73-78.

Schreiber, E. S. G., P. S. Lake \& G. P. Quinn, 2002. Facilitation of native stream fauna by an invading species? Experimental investigations of the interaction of the snail, Potamopyrgus antipodarum (Hydrobiidae) with native benthic fauna. Biological Invasions 4: 317-325.

Sieratowicz, A., U. Schulte-Oehlmann, A. Wigh \& J. Oehlmann, 2013. Effects of test media on reproduction in Potamopyrgus antipodarum and of pre-exposure population densities on sensitivity to cadmium in a reproduction test. Journal of Environmental Science and Health - Part A 48: 481-488.

Smith, E. A., 1889. Notes on British Hydrobiae with a description of a supposed new species. Journal of Conchology 6: 142-145.

Sorte, C. J. B., S. L. Williams \& J. T. Carlton, 2010. Marine range shifts and species introductions: comparative spread rates and community impacts. Global Ecology and Biogeography 19: 303-316.

Städler, T., M. Frye, M. Neiman \& C. M. Lively, 2005. Mitochondrial haplotypes and the New Zealand origin of clonal European Potamopyrgus, an invasive aquatic snail. Molecular Ecology 14: 2465-2473.

Sultan, S., 1995. Phenotypic plasticity and plant adaptation. Acta Bontanica Neerlandica 44: 363-383.

Tobin, P. C., L. Berec \& A. M. Liebhold, 2011. Exploiting Allee effects for managing biological invasions. Ecology Letters 14: 615-624. 
Verhaegen, G., K. E. McElroy, L. Bankers, M. Neiman \& M. Haase, 2018a. Adaptive phenotypic plasticity in a clonal invader. Ecology and Evolution 8: 4465-4483.

Verhaegen, G., M. Neiman \& M. Haase, 2018b. Ecomorphology of a generalist freshwater gastropod: complex relations of shell morphology, habitat, and fecundity. Organisms Diversity \& Evolution 18: 425-441.

Verhaegen, G., H. Herzog, K. Korsch, G. Kerth, M. Brede \& M. Haase, 2019. Testing the adaptive value of gastropod shell morphology to flow: a multidisciplinary approach based on morphometrics, computational fluid dynamics and a flow tank experiment. Zoological Letters 5: 1-13.

Vinson, M. R. \& M. A. Baker, 2008. Poor growth of rainbow trout fed New Zealand mud snails Potamopyrgus antipodarum. North American Journal of Fisheries Management 28: 701-709.

Vitousek, P. M., C. M. D’Antonio, L. L. Loope \& R. Westbrooks, 1996. Biological invasions as global environmental change. American Scientist 84: 218-228.

Wallace, C., 1985. On the distribution of the sexes of Potamopyrgus jenkinsi (Smith). Journal of Molluscan Studies 51: 290-296.

Weetman, D., L. Hauser \& G. R. Carvalho, 2002. Reconstruction of microsatellite mutation history reveals a strong and consistent deletion bias in invasive clonal snails, Potamopyrgus antipodarum. Genetics Society of America 162: 813-822.
Winterbourn, M. J., 1969. Water temperature as a factor limiting the distribution of Potamopyrgus antipodum (GastropodaProsobranchia) in the New Zealand thermal region. New Zealand Journal of Marine and Freshwater Research 3: 453-458.

Winterbourn, M. J., 1970a. Population studies on the New Zealand freshwater gastropod Potamopyrgus antipodarum (Gray). Journal of Molluscan Studies 39: 139-149.

Winterbourn, M. J., 1970b. The New Zealand species of Potamopyrgus (Gastropoda: Hydrobiidae). Malacologia 10: 283-321.

Winterbourn, M. J., 1974. Larval Trematoda parasitizing the New Zealand species of Potamopyrgus (Gastropoda: Hydrobiidae). Mauri Ora 2: 17-30.

Zachar, N. \& M. Neiman, 2013. Profound effects of population density on fitness-related traits in an invasive freshwater snail. PLoS ONE 8: 1-6.

Zbikowski, J. \& E. Zbikowska, 2009. Invaders of an invader: trematodes in Potamopyrgus antipodarum in Poland. Journal of Invertebrate Pathology 101: 67-70.

Publisher's Note Springer Nature remains neutral with regard to jurisdictional claims in published maps and institutional affiliations. 